\title{
Dense adhesions between the uterus and anterior abdominal wall: a unique complication of Cesarean delivery
}

\author{
Dan Levin • Togas Tulandi
}

Received: 2 September 2010 /Accepted: 27 September 2010 / Published online: 22 October 2010

(C) Springer-Verlag 2010

Keywords Adhesions $\cdot$ Cesarean $\cdot$ Complication

In the past decade, the rates of Cesarean delivery have continued to rise, reaching $30.3 \%$ in 2005 -the highest level reported in the US. This level marks a $46 \%$ increase from 1996, when the Cesarean delivery rate was $20.7 \%$ [1]. Similar to other abdominal operations, Cesarean delivery is associated with intra-abdominal adhesions. However, in contrast to other abdominal operations, the impact of post-Cesarean adhesions and prevention of their formation have not been widely studied. These adhesions can cause a difficulty entering the abdominal cavity at subsequent surgery leading to longer time to deliver the baby at repeat Cesarean, and increased risk of bowel and bladder injury [2-6]. Other possible effects of intraabdominal adhesions include abdominal pain and bowel obstruction [7].

In attempts to decrease adhesion formation, several authors have evaluated different surgical techniques. For example, Blumenfeld et al. [8] reported that single layer closure of the hysterotomy incision was associated with more bladder adhesions at the time of repeat Cesarean than double layer closure. There is also evidence that that nonclosure of the peritoneum after Cesarean section is associated with more adhesion formation compared to closure [9]. Unfortunately, there are very few studies that

D. Levin $\cdot$ T. Tulandi $(\bowtie)$

Department of Obstetrics and Gynaecology, McGill University,

Women's Pavilion, 687 Pine Avenue West,

Montreal H3A 1A1 Quebec, Canada

e-mail: togas.tulandi@mcgill.ca have looked at adhesions after Cesarean delivery in the literature. Most studies evaluating post-surgical adhesion formation rely on second-look laparoscopy. However, the inconvenience of a second-look procedure especially in postpartum women contributes to the paucity of information on post-Cesarean adhesions.

Our case is a 65-year-old woman who underwent laparoscopic total hysterectomy and bilateral salpingooophorectomy. She experienced chronic lower abdominal pain since her Cesarean delivery 33 years before the present surgery. At laparoscopy, the uterus was found to be in traction and adhered to the anterior abdominal wall (Fig. 1). Her abdominal pain disappeared following surgery. Whether the use of adhesion preventing substance would have prevented her chronic abdominal pain is unknown. In any event, one should start evaluating ways to reduce postCesarean adhesions.

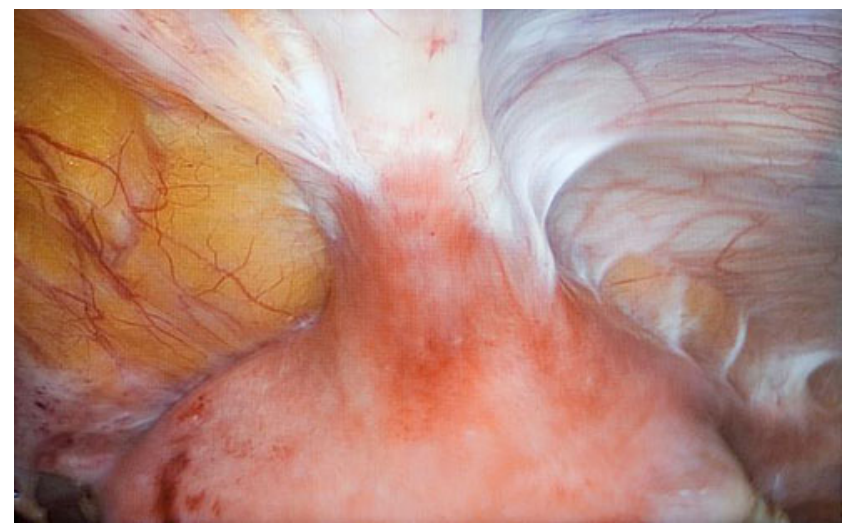

Fig. 1 Laparoscopic photograph of dense adhesions between the uterus and the anterior abdominal wall 
Conflict of interest Prof. Togas Tulanda received a research grant from Ethicon Inc.

\section{References}

1. Hamilton BE, Martin JA, Ventura SJ (2007) Births: preliminary data for 2006. Natl Vital Sat Rep 56:1-18

2. Morales KJ, Gordon MC, Bates GW Jr (2007) Postcesarean delivery adhesions associated with delayed delivery of infant. Am J Obstet Gynecol 196(461):e461-e466

3. Phipps MG, Watabe B, Clemons JL, Weitzen S, Myers DL (2005) Risk factors for bladder injury during Cesarean delivery. Obstet Gynecol 105:156-160

4. Nisenblat V, Barak S, Griness OB, Degani S, Ohel G, Gonen R (2006) Maternal complications associated with multiple Cesarean deliveries. Obstet Gynecol 108:21-26
5. Silver RM, Landon MB, Rouse DJ, Leveno KJ, Spong CY, Thom EA, Moawad AH, Caritis SN et al (2006) Maternal morbidity associated with multiple repeat Cesarean deliveries. Obstet Gynecol 107:1226-1232

6. Tulandi T, Agdi M, Zarei A, Miner L, Sikirica V (2009) Adhesion formation and morbidity after repeat Cesarean delivery. Am J Obstet Gynecol 201(56):e.1-e.6

7. van Goor H (2007) Consequences and complications of peritoneal adhesions. Colorectal Dis 9(Suppl 2):25-34

8. Blumenfeld YJ, Caughey AB, El-Sayed YY, Daniels K, Lyell DJ (2010) Single- versus double-layer hysterotomy closure at primary Cesarean delivery and bladder adhesions. BJOG Int J Obstet Gynaecol 117:690-694

9. Cheong YC, Premkumar G, Metwally M, Peacock JL, Li TC (2009) To close or not to close? a systematic review and a meta-analysis of peritoneal non-closure and adhesion formation after Cesarean section. Eur J Obstet Gynecol Reprod Biol $147: 3-8$ 